\title{
Social protection for developing countries: Can social insurance be more relevant for those working in the informal economy?*
}

\author{
NICOLA SMIT \\ Professor, Department of Mercantile Law, Faculty of Law, University of \\ Johannesburg \\ LETLHOKWA GEORGE MPEDI \\ Associate Professor, Department of Mercantile Law, Faculty of Law, University of \\ Johannesburg
}

\section{INTRODUCTION}

In Southern Africa ${ }^{1}$ workers in the informal economy and their dependants are for the most part completely excluded from (formal) social protection schemes, in particular social insurance schemes. ${ }^{2}$ This is due to the fact that most social insurance schemes link the concept of contributor to that of employee. ${ }^{3}$ This is problematic, since the notion "employee" is by and large used to refer only to "standard" formal sector workers. ${ }^{4}$ Occupational and

\footnotetext{
* This article is based on a paper presented at the Fifteenth International Research Seminar of the Foundation for International Studies on Social Security on "Issues in Social Security", Sigtuna, Sweden, 13-15 June 2008.

${ }^{1}$ Southern African countries are generally defined as Angola, Botswana, Lesotho, Madagascar, Malawi, Mauritius, Mozambique, Namibia, South Africa, Swaziland, Zambia, and Zimbabwe: Haddad "Overview" in Haddad (ed) Achieving Food Security in Southern Africa: New Challenges, New Opportunities (International Food Policy Research Institute, 1997) 3 at 3.

2 Olivier and Mpedi "The extension of social protection to non-formal sector workers experiences from SADC and the Caribbean" (2005) 19 Zeitschrift für ausländisches und internationales Arbeits- und Sozialrecht (ZIAS) 144 at 150-152.

${ }^{3}$ Ibid.

${ }^{4}$ Ibid.
} 
public social insurance schemes therefore generally limit their scope to traditional or typical formal sector employees. ${ }^{5}$ According to Van Ginneken, about one-third of people in the world are not covered by any formal social security protection, ${ }^{6}$ which suggests that the above framework can no longer suffice.

The main reason for the exclusion of workers in the informal economy from statutory social security coverage has been described by Van Ginneken as the fact that these workers "are unable or unwilling to contribute a relatively high percentage of their incomes to financing social security benefits that do not meet their priority needs". ${ }^{7}$ This naturally leads to the need for researchers to determine the priority needs of workers in the informal economy and explore ways of extending social protection to such workers. The needs and aspirations of those working in the informal economy may be said to pertain to two related issues: the first is to improve and maximise their employment potential and the second is to extend their coverage under social protection measures. $^{8}$

The authors seek to reflect on the "informal economy" since a commitment to "full employment" and a "decent standard of living" necessarily embraces both formal and informal employment. Furthermore, in our poverty-stricken region $^{9}$ policies and strategies should take account of both the formal and informal economies. In addition, they should steer clear of the conception that social assistance is (or should be) the panacea of the social protection coverage challenges of informal economy workers in developing countries. This view

5 ibid.

${ }^{6}$ Van Ginneken "Social security for the informal sector: Issues, options and tasks ahead" ILO Working Paper (1996) Introduction available at http://www.ilo.org/public/english/ protection/soecsec/publ/wouter2.

7 Van Ginneken "Extending social security: Policies for developing countries" (ESS Paper No 13, 2003) 9. See, however, the discussion in par 3 below.

8 Some authors caution that demands by informal workers for better security and protection "can easily lead to increased vulnerability of employment - as they can be easily replaced": Chen, Jhabvala and Lund "Supporting workers in the informal economy: A policy framework" Employment Sector Working Paper on the Informal Economy (ILO 2002/2) 36. However, the authors then continue to plead the case for social protection for informal economy workers on two grounds: "first and foremost, in terms of their basic human rights; and second, on the grounds that a healthier and more secure work force increases productivity".

9 See, for example, Mpedi "Unemployment protection in the Southern African Development Community: Trends and Challenges" (2008) 22 ZIAS 271 at 272-273. 
presupposes that informal economy workers do not have the requisite contributory capacity to participate in social insurance schemes. This is not entirely true as some of these workers could contribute, given an opportunity to participate in social insurance programmes or should these programmes be tailored to their needs (e.g. setting contributions in accordance with informal economy workers' (limited) contributory capacity). Secondly, social assistance is an integral part of social protection measures which include social insurance, and the benefits provided by the respective measures are geared to different goals.

On the one hand, social assistance benefits are primarily aimed at ensuring that individuals do not fall below a certain basic minimum level of existence. On the other hand, social insurance benefits are largely focussed on income replacement. In addition, there is an issue of affordability which should be borne in mind. The extent to which a developing country can broaden the scope of its social assistance measures (at least where they exist) so as to incorporate vulnerable members of the society depends largely on the state of its financial affairs. Limited resources, a characteristic of most developing countries, invariably restrict the scope of social assistance coverage and/or the speed at which social assistance measure can be extended.

In this article the term "social insurance" refers to (often employmentbased) public schemes devised to achieve income maintenance or replacement by providing earnings-related benefits. Benefits are derived from employee and/or employer contributions, and the state may also contribute to such schemes or guarantee certain benefits. The "insurance" is obligatory and aims to promote and achieve social solidarity. To this end, informal economy workers who can protect themselves and their dependants against social risks through appropriate social insurance measures should be afforded such an opportunity. Only those needy informal economy workers who could not (adequately) protect themselves against social risks should be accommodated through social assistance mechanisms. This approach is in line with the principle that persons with the means to provide for their social security needs and those of their dependants should do so. In other words, social assistance is (or should be) supplemental to social insurance. To achieve this goal, social insurance measures should be made more appropriate to the informal economy workers so as to enable those who can protect themselves against social security risks to do so while they can.

The article is divided into four sections. The first presents an analysis of conceptual issues relevant to the present enquiry. The second describes the labour market and social protection challenges to be considered in endeavours 
to make social insurance relevant to informal economy workers in Southern Africa. The third section discusses possible recommendations to make social insurance more relevant to those toiling in the informal economy, on the one hand by considering ways to extend social protection to those workers and their families and, on the other hand, to investigate to what extent it is possible to strengthen the linkages between the two economies. The final part presents some remarks on the way forward.

\section{CONCEPTUAL ISSUES}

\subsection{The informal economy}

The term "informal sector" was first coined by the International Labour Organisation (the ILO) to

"describe the economic activities being carried out by the poor who were not recognised, regulated or protected by the public authorities. In fact, the informal sector/economy absorbs excess labour not being employed in the formal sector." 10

Nowadays the expression "informal sector" has given way to the term "informal economy"; however, this term is also not universally accepted.11 What is clear is that workers in the informal economy are not covered by labour legislation, tend to work in small workplaces, often work for themselves, have unsafe and unhealthy work conditions, low levels of skills, low and irregular incomes, lack of access to assets, credit, finance, training, information and technology, and often form vulnerable groups in society. Workers in the informal economy include both wage workers and ownaccount workers. This is reinforced by the South African Labour Force Survey (the LFS) which explains the "informal sector" as follows:

\footnotetext{
10 See Shrestha "Social protection in the informal economy" available at www.nepal democracy,org/institutions/Informal Economy.htm and International Labour Conference (ILC) "Conclusions concerning decent work and the informal economy" (ILO 90 $0^{\text {th }}$ session, 2002) par 6.

11 Ibid par 3: "Although there is no universally accurate or accepted description or definition there is a broad understanding that the term 'informal economy' accommodates considerable diversity in terms of workers, enterprises and entrepreneurs with identifiable characteristics...The term 'informal economy' is preferable to 'informal sector' because the workers and enterprises in question do not fall within any one sector of economic activity, but cut across many sectors. However, the term 'informal economy' tends to downplay the linkages, grey areas and interdependencies between formal and informal activities."
} 
"The informal sector consists of those businesses that are not registered in any way. They are generally small in nature, and are seldom run from business premises. Instead, they are run from homes, street pavements or other informal arrangements". ${ }^{12}$

The ILO describes the "informal economy" as referring to

"all economic activities by workers and economic units that are - in law or in practice - not covered or insufficiently covered by formal arrangements. Their activities are not included in the law, which means that they are operating outside the formal reach of the law; or they are not covered in practice, which means that, although they are operating within the formal reach of the law, the law is not applied or not enforced; or the law discourages compliance because it is inappropriate, burdensome, or imposes excessive costs". 13

According to Valodia ${ }^{14}$ the most quoted definition is that contained in the ILO's Kenya Report, "in which informal activities are defined as 'a way of doing things', characterised by:
a) ease of entry;
b) reliance on indigenous resources;
c) family ownership of enterprises;
d) small scale of operation;
e) labour-intensive and adapted technology;
f) skill acquired outside of the formal school system; and
g) unregulated and competitive markets." 15

This notion of the informal economy thus embrace many different types of economic activities, including both enterprise and work relationships. Trebilcock does note that a criticism sometimes made of the definition is "that persons engaged in very small-scale or casual self-employment activities may not report in statistical surveys that they are self-employed, or employed at all,

\footnotetext{
12 Statistics South Africa Labour Force Survey: September 2007 (Statistics South Africa (2007)) xxvi. The official definition to determine informal employment in South Africa is based on a self-classification question in the LFS.

${ }^{13}$ Hussmanns Measuring the informal economy: From employment in the informal sector to informal employment Working Paper No. 53 (ILO Policy Integration Department Bureau of Statistics, 2004).

14 Valodia "Formal/informal linkages in South Africa: Some considerations" (HSRC 2006) 1-2.

15 (1972) 6.
} 
although their activity falls within the enterprise-based definition". ${ }^{16}$ Anther criticism highlighted by Trebilcock is that "informal sector statistics may be affected by errors in classifying certain groups of employed persons by status in employment, such as outworkers, subcontractors, free-lancers or other workers whose activity is at the borderline between self-employment and wage employment."17 For statistical purposes it is therefore clear that the definitions of both "employment in the informal sector" and "informal employment" are concepts that are relevant and refer to different aspects of the "informalisation" of employment. ${ }^{18}$ It should also be noted that there are linkages between the formal and informal economy which need to be explored further and, if possible, strengthened.

The ILO distinguishes the informal economy from "criminal and illegal activities, such as production and smuggling of illegal drugs". 19 This contribution makes the same distinction.

It is safe to say that in Southern Africa most workers in the informal economy do not work there by choice; they are poorly paid and have little hope of migrating to the formal economy due to lack of formal skills. However, in this article a distinction is drawn between low-wage workers and workers in the informal economy. The first group are not dealt with in this article even though they are also vulnerable workers. ${ }^{20}$ The concept of self-employed persons must also be unpacked to recognise that there may, at the one

16 Trebilcock Decent Work and the Informal Economy (EGDI/UNI-WIDER Discussion Paper 2005/04) 2, 14.

$17 \mathrm{ibid}$.

18 ibid. See also Theron "Employment is not what it used to be" (2003) 24 ILJ 1247.

19 ILC (n 10) par 5.

20 See Valodia, Lebani and Skinner "Low-waged and informal employment in South Africa" (School of Development Studies, University of KwaZulu-Natal, October 2005) at 8: "We see that low-waged employment is particularly concentrated in subsistence agriculture, domestic work, commercial agriculture and the informal economy. Using a cut-off of R1 000, 14.6\% of workers in the formal economy may be classified as low-waged in 2004 . However, $44.4 \%$ of formal workers earn incomes below R2 500 per month." It is also shown that trade union membership among the low-waged is negligible. The authors indicate (at 11 that) "[o]nly a small proportion of those earning below R1 000 per month have trade union membership, and access to trade union services. At the higher level of R2 500, just under one-fifth of workers belong to trade unions... Trade union membership is associated with higher income brackets for both periods. There is less than $10 \%$ of workers earning R500 or less who are members of a trade union." 
extreme, be vulnerable workers with very low wages and, at the other extreme, professional people who fall under this generic classification.

There are two main elements that can be gleaned from the LFS's definition of "informal sector" which are used to identify informal sector enterprises, namely non-registration and the size of the enterprise.

Non-registration of an informal economy business can be unpacked into two aspects: firstly, it entails the non-registration of an informal sector enterprise in terms of relevant national laws (e.g. company, tax or social security laws). ${ }^{21}$ It should be pointed out that the formation and employment of persons in informal sector enterprises is not wholly driven by illicit goals (e.g., evading the taxman). In developing countries, such as those in Southern Africa, there are other factors such as high unemployment and poverty which drive the growth of informal sector activities. Secondly, informal sector businesses involve the non-registration of employees in the sense that there is no employee-employer contract committing the employer to pay the applicable taxes and social security contributions on behalf of the employee making the employment relationship subject to labour laws. ${ }^{22}$ However, this does not presuppose that tax and social security duties of the employer to pay contributions in respect of employees depend on the existence of a contract of employment. Some of these duties are imposed ex lege. ${ }^{23}$ The small size of an enterprise, on the other hand, relates to the number of persons employed in the business and not to economic considerations such as annual turnover. However, there is a tendency to exclude agricultural activities and household enterprises from the ambit of the informal economy. It has been reported that atypical work is statistically highest in construction, agriculture, domestic work, followed by wholesale and retail.24

South Africa is a case in point, as is shown by the table below:

\footnotetext{
${ }^{21}$ Braude "South Africa: Bringing informal workers into the regulated sphere, overcoming Apartheid's legacy" in Avirgan et al (eds) Good Jobs, Bad Jobs, No Jobs: Labor Markets and Informal Work in Egypt, El Salvador, India, Russia and South Africa (Economic Policy Institute, 2005) 369 at 419.

22 Ibid at 420.

23 E.g., the employer's duty in South Africa to deduct and pay contributions to the Unemployment Insurance Fund or the South African Revenue Services.

${ }^{24}$ See Mills "The situation of the elusive independent contractor and other forms of atypical employment in South Africa: Balancing equity and flexibility" (2004) 25 ILJ 1203 at 1211.
} 


\section{Employment in the South African formal and informal economy:}

September 2001 to September 2007

\begin{tabular}{|c|c|c|c|c|c|c|c|}
\hline Sector & Sep'01 & Sep'02 & Sep'03 & Sep'04 & Sep'05 & Sep'06 & Sep'07 \\
\hline Formal sector (excluding agric) & 7027 & 7181 & 7373 & 7692 & 7987 & 8384 & 8785 \\
\hline Informal sector (excluding agric) & 1967 & 1780 & 1903 & 1946 & 2462 & 2379 & 2122 \\
\hline Domestic workers & 881 & 844 & 895 & 881 & 859 & 886 & 1057 \\
\hline Agriculture & 1178 & 1420 & 1212 & 1063 & 925 & 1088 & $1164 \|$ \\
\hline Unspecified & 128 & 72 & 40 & 60 & 67 & 64 & 106 \\
\hline Total employment & 11181 & 11296 & 11424 & 11643 & 12301 & 12800 & 13234 \\
\hline & & & & Percent & & & \\
\hline Formal sector (excluding agric) & 62.8 & 63.6 & 64.5 & 66.1 & 64.9 & 65.5 & 66.4 \\
\hline Informal sector (excluding agric) & 17.6 & 15.8 & 16.7 & 16.7 & 20.0 & 18.6 & 16.0 \\
\hline Domestic workers & 7.9 & 7.5 & 7.8 & 7.6 & 7.0 & 6.9 & 8.0 \\
\hline Agriculture & 10.5 & 12.6 & 10.6 & 9.1 & 7.5 & 8.5 & 8.8 \\
\hline Total & 100.0 & 100.0 & 100.0 & 100.0 & 100.0 & 100.0 & 100.0 \\
\hline
\end{tabular}

Source: Statistics South Africa Labour Force Survey: September 2007

This article will not address the reasons for the growth of the informal economy and of atypical, casual and non-permanent work arrangements. They mostly pertain to flexibility and profit-maximising concerns. Some also argue that "in the face of high rates of unemployment and low rates of growth in gross domestic product it is better to have individuals employed in such forms of employment since in the long run their use would stimulate growth in employment and output". 25

The important point to recognise is that it is much more likely that the informal economy will remain with us and even expand rather than decrease in size or scope. Once this fact is acknowledged, all new policies or changes to existing policy frameworks must be seen to take note of the informal economy. If not, labour law and social protection may become completely irrelevant to the majority of people in South Africa and the region.

\footnotetext{
25 These arguments are summarised in Theron "Atypical forms of work and employment and their policy implications" (1998) 19 ILJ 197 at 197-198. See also Thompson "The Changing Nature of Employment" (2003) 24 ILJ 1793 at 1815: "Work has changed and is changing for both better and for worse. On the positive side, there are now many more options open to employees, allowing them to work in more flexible ways and so better match their work obligations with their lifestyle aspirations. ... On the downside, however, a restructured workplace has meant that some employees have been placed under considerably more workplace pressures while others have been displaced into more precarious and less wellrewarded job roles".
} 
Chen has developed a useful table to illustrate the "old and new views of the informal economy":26

\begin{tabular}{|c|c|}
\hline $\begin{array}{l}\text { The informal sector is the } \\
\text { traditional economy that } \\
\text { will wither away and die } \\
\text { with modern, industrial } \\
\text { growth. }\end{array}$ & $\begin{array}{l}\text { The informal economy is "here to stay" and } \\
\text { expanding with modern industrial growth. }\end{array}$ \\
\hline $\begin{array}{l}\text { It is only marginally } \\
\text { productive. It is a major } \\
\text { provider of employment, } \\
\text { goods and services for } \\
\text { lower-income groups. }\end{array}$ & It contributes a significant share of GDP. \\
\hline $\begin{array}{l}\text { It exists separately from } \\
\text { the formal economy. }\end{array}$ & $\begin{array}{l}\text { It is linked to the formal economy - it produces } \\
\text { for, trades with, distributes for and provides } \\
\text { services to the formal economy. }\end{array}$ \\
\hline $\begin{array}{l}\text { It represents a reserve pool } \\
\text { of surplus labour. }\end{array}$ & $\begin{array}{l}\text { Much of the recent rise in informal } \\
\text { employment is due to the decline in formal } \\
\text { employment or to the informalisation of } \\
\text { previously formal employment relationships. }\end{array}$ \\
\hline $\begin{array}{l}\text { It is comprised mostly of } \\
\text { street traders and very } \\
\text { small-scale producers. }\end{array}$ & $\begin{array}{l}\text { It is made up of a wide range of informal } \\
\text { occupations - both "resilient old forms" such as } \\
\text { casual day labour in construction and } \\
\text { agriculture as well as "emerging new ones" } \\
\text { such as temporary and part-time jobs plus } \\
\text { homework for high-tech industries. }\end{array}$ \\
\hline $\begin{array}{l}\text { Most of those in the sector } \\
\text { are entrepreneurs who run } \\
\text { illegal and unregistered } \\
\text { enterprises in order to } \\
\text { avoid regulation and } \\
\text { taxation. }\end{array}$ & $\begin{array}{l}\text { It is made up of non-standard wage workers as } \\
\text { well as entrepreneurs and-self employed } \\
\text { persons producing legal goods and services, } \\
\text { albeit through irregular or unregulated means. } \\
\text { Most entrepreneurs and the self-employed are } \\
\text { amenable to, and would welcome, efforts to } \\
\text { reduce barriers to registration and related } \\
\text { transaction costs and to increase benefits from } \\
\text { regulation; and most informal wage workers } \\
\text { would welcome more stable jobs and workers' } \\
\text { rights. }\end{array}$ \\
\hline
\end{tabular}

${ }^{26}$ Chen "Rethinking the Informal Economy: Linkages with the Formal Economy and the Formal Regulatory Environment" DESA Working Paper No. 46 (July 2007) at 5. 
Work in the informal economy is comprised mostly of survival activities and thus is not a subject for economic policy.
Informal enterprises include not only survival activities but also stable enterprises and dynamic growing businesses, and informal employment includes not only selfemployment but also wage employment. All forms of informal employment are affected by most (if not all) economic policies.

\subsection{The elusive employee}

In South Africa most labour statutes define an employee as

"any person, excluding an independent contractor, who works for another person or for the State and who receives, or is entitled to receive, any remuneration; and

"any other person who in any manner assists in carrying on or conducting the business of an employer." 27

There is also a presumption ${ }^{28}$ that assists workers who must prove that they are "employees":

"(1) Until the contrary is proved, a person who works for, or renders services to, any other person is presumed, regardless of the form of the contract, to be an employee, if any one or more of the following factors are present [own emphasis]:

(a) the manner in which the person works is subject to the control or direction of another person;

(b) the person's hours of work are subject to the control or direction of another person;

(c) in the case of a person who works for an organisation, the person forms part of that organisation;

(d) the person has worked for that other person for an average of at least 40 hours per month over the last three months;

(e) the person is economically dependent on the other person for whom he or she works or renders services;

27 S 213 of the Labour Relations Act 66 of 1995 (LRA); the definition in s 1 of the Basic Conditions of Employment Act 75 of 1997 (BCEA) is identical and that in s 1 of the Employment Equity Act 55 of 1998 (EEA) near-identical. The definitions of "employee" or "worker" in social security legislation have not been updated to coincide with that found in the labour statutes: see par 4 below. For further reading on the evolving nature of work, see Thompson (n 25).

${ }^{28}$ See $200 \mathrm{~A}$ of the LRA and $\mathrm{s} 83 \mathrm{~A}$ of the BCEA. 
(f) the person is provided with tools of trade or work equipment by the other person; or

(g) the person only works for or renders services to one person.

"(2) Subsection (1) does not apply to any person who earns in excess of the amount determined by the Minister in terms of section 6(3) of the Basic Conditions of Employment Act."

An important step forward was taken when the LRA included the notion of a temporary employment service in section 198 of the Act. The section deems the labour-broking firm to be the employer of the subcontracted worker and, in addition, creates joint and several liability in certain circumstances (e.g. in the case of contravention of legislation, arbitration awards or sectoral determinations in terms of the BCEA). In certain instances the Minister of Labour may also "deem" certain categories of persons as "employees" for purposes of the Unemployment Insurance Act 63 of $2001.2^{29}$ Although this section is certainly not above criticism, its underlying principle of expressly providing that workers employed by these services are "employees" cannot be faulted.

It is often remarked that atypical employment is becoming more typical. As far back as 1998 Mhone commented that, once atypical forms of employment become generalised, they "become self-reproducing with various rationalisations being cited for their desirability and continuation". ${ }^{30}$ Some of these rationalisations include: the lowering of production costs and increase of output, thus enhancing competitiveness and, ultimately, employment; overcoming "barriers" to productive activities, such as allowing persons who would otherwise be prevented from participating due to, for example, the reproductive role of women, to work from home; and enhancing job satisfaction by allowing flexibility in work. In fact, Mhone submits that the emergence of atypical forms of work and employment "is fraught with both benefits and costs, and that for a country ... the policy thrust should be to search for modes of labour utilisation that enhance both flexibility and security". ${ }^{31}$ However, as this author himself acknowledges, this is easier said than done.

\footnotetext{
${ }^{29} \mathrm{~S} 83(1)$ of the BCEA.

30 Mhone "Atypical Forms of Work and Employment and Their Policy Implications" (1998) 19 ILJ 197 at 209. See, in general, Olivier "Extending Labour Law and Social Security Protection: The Predicament of the Atypically Employed" (1998) 19 ILJ 669.

${ }^{31}$ Mhone (n 30) at 212.
} 
It is regrettable that social security legislation has not kept up with developments in labour legislation. ${ }^{32}$ The current interpretation of the definition of employee is further discussed in paragraph 4 below.

\subsection{Social protection/social security}

\subsubsection{What is included under the notion social protection?}

The ILO defines social security as

"[t]he protection which society provides for its members, through a series of public measures, against the economic and social distress that otherwise will be caused by the stoppage or substantial reduction of earnings resulting from sickness, maternity, employment injury, unemployment, invalidity, old age and death; the provision of medical care; and the provision of subsidies for families and children." 33

Social protection is a wide term encompassing social security measures and even more. It refers to a wide variety of instruments designed to ensure that human beings are adequately protected against social, economic and other risks. $^{34}$ In the past it has sometimes been said that social security is the

\footnotetext{
32 The Compensation for Occupational Injuries and Diseases Act of 1993 defines an "employee" as "[a] person who has entered into or works under a contract of service or of apprenticeship or learnership, with an employer, whether the contract is express or implied, oral or in writing and whether the remuneration is calculated by time or work done, or is in cash or in kind, and includes ...". The Occupational Health and Safety Act of 1993 defines an "employee" as "any person who is employed by or works for an employer and who receives or is entitled to receive any remuneration or who works under the direction or supervision of an employer or any other person." The definition in the Unemployment Insurance Act of 2003, as is the case with the labour law definitions, is capable of a wider interpretation: "any natural person who receives remuneration or to whom remuneration accrues in respect of services rendered or to be rendered by that person, but excludes any independent contractor".

33 ILO Convention 102 of 1952; ILO Introduction to Social Security (1984) 3.

34 Social protection is also said to comprise "policies and programmes designed to reduce poverty and vulnerability by promoting efficient labour markets, diminishing people's exposure to risks, enhancing their capacity to protect themselves against hazards and interruption/loss of income": Asian Development Bank "Social Protection: Reducing risks, increasing opportunities" (March 2010) at http://www.adb.org/SocialProtection/default.asp). The aim of social protection, for that reason, is to avert or minimise social risks - in that way preventing or minimising human damage - by increasing capabilities and opportunities. See, e.g., United Nations Enhancing Social Protection and Reducing Vulnerability in a Globalising
} 
protection which society provides for its members through a series of public measures. ${ }^{35}$ However, this is a narrow view and should be broadened to refer to basic needs and all relevant contingencies. Barrientos states that a renewed social protection aim is to combine protection of living standards with support for the investment in human development needed to reduce the vulnerability of households to economic risk. ${ }^{36}$ The authors prefer this wider notion of social protection. ${ }^{37}$

ILO activities in the field of social protection are mainly rooted in the Declaration of Philadelphia of 10 May 1944, the concept of decent work ${ }^{38}$ and the relevant ILO social security standards. ${ }^{39}$ It has been said that the mandate of the ILO is social justice as the basis for peace. ${ }^{40}$ Recognising the significance of informal economies, the ILO has in recent years placed more emphasis on the notion of decent work in its strategies relating to the informal economy.

World: Report of the Secretary-General (39th Session of the Commission for Social Development, 2000).

35 However, public measures do not even begin to cover the majority of people in developing countries. Some authors have lamented the fact that many discussions of the role of nonformal social welfare systems in the industrialised world have ignored the growing literature on the subject emanating from the Third World where such informal measures are entrenched and widely relied upon: Midgley and Sherraden (eds) Alternatives to Social Security: An International Inquiry (1997) 118.

36 Barrientos "Extending social protection for women informal workers in Latin America" (2005) 5 (a copy of this paper is on file with the author). See Smit "Decent work and the promotion of access to social protection for workers in the informal economy - an international and regional perspective" 20074 TSAR 700-715.

37 The ILO conceptualises social protection as including social security and labour protection: see Van Ginneken (n 6) 10. Labour market policies and social services should also be included; in this regard Van Ginneken comments: "It is also important to note already here that the goal and the concept of decent work, matches this broader view of social security/social protection" (ibid 10).

${ }^{38}$ See International Labour Office Report of the Director General: Decent Work (87 ${ }^{\text {th }}$ Session, 1999).

39 For example, the Social Security (Minimum Standards) Convention 102 of 1952, the Medical care and Sickness Benefits Convention 130 of 1969, the Employment Promotion and Protection against Unemployment Convention 168 of 1988, the Invalidity, Old-Age and Survivors benefits Convention 128 of 1967, the Employment Injury Benefits Convention 121 of 1964, the Maternity Protection Convention 183 of 2000 and the Equality of Treatment (Social Security) Convention 157 of 1982.

40 See, for example, International Labour Office Decent Work and the Informal Economy (International Labour Conference, $90^{\text {th }}$ Session, 2002). 
One of the main characteristics of the decent work strategy is that everybody is entitled to basic social security. ${ }^{41}$ In Southern Africa this is, unfortunately, very far from what the position is on the ground. Although the ILO has placed much emphasis on the promotion of the concepts of a "decent job" and a "decent wage", Southern Africa has not yet managed to reach this level, and certainly not in its informal economies. As in other developing countries, therefore, informal social security remains the primary vehicle through which many people receive some form of social protection. ${ }^{42}$

Social security standards are traditionally manifested in three main forms: ${ }^{43}$

- First-generation standards. These standards are mainly based on the notion of social insurance and are applicable to certain categories of workers, with no universal application.

- Second-generation standards. These standards adopt a broader approach by paying attention to providing a basic income to all in need of such protection. ${ }^{44}$

- Third-generation standards. These standards offer a higher level of protection, both with reference to the sections of the population covered and the level of benefits.

In most developing countries, including those in Southern Africa, it is predominantly first-generation standards that are applicable.

\subsubsection{Access to social protection}

It is submitted that social protection, which includes social insurance, is a fundamental right which is (or should be) enjoyed by every person irrespective of the sector/type of economy in which he or she is employed.

\footnotetext{
${ }^{41}$ See again art 9 of the International Covenant of Economic, Social and Cultural Rights. Van Ginneken (n 6) therefore comments that a decent work strategy aims at universality of coverage: at 11 .

42 In this regard, see Dekker "Mind the gap: Suggestions for bridging the divide between formal and informal social security" (2008) 12 LDD 117.

${ }^{43}$ ILO (Humblet \& Silva) Standards for the XXIst Century: Social Security (2002) 2.

44 ILO Convention 102 of 1952 (Social Security Minimum Standards Convention) provides for a minimum level of benefits in nine branches of social security (namely medical care, sickness, unemployment, old age, employment injury, family, maternity, invalidity and survivors' benefits).
} 
This is apparent from the international instruments such as the Universal Declaration of Human Rights (1948), the International Covenant on Economic, Social and Cultural Rights (1966) and the Charter of Fundamental Social Rights in the Southern African Development Community (the SADC charter) (2003):

- The Universal Declaration of Human Rights. Article 22 of the Universal Declaration of Human Rights provides every person, as a member of society, with a right to social security. It further provides:

"Everyone who works has the right to just and favourable remuneration ensuring for himself and his family an existence worthy of human dignity, and supplemented, if necessary, by other means of social protection" (article 23(3)).

In addition, article 25 states:

"Everyone has the right to a standard of living adequate for the health and well-being of himself and of his family, including food, clothing, housing and medical care and necessary social services, and the right to security in the event of unemployment, sickness, disability, widowhood, old age or other lack of livelihood in circumstances beyond his control. Motherhood and childhood are entitled to special care and assistance. All children, whether born in or out of wedlock, shall enjoy the same social protection."

- International Covenant on Economic, Social and Cultural Rights. Article 9 of this instrument recognises social security, including social insurance, as a fundamental right. Article 10(2) moreover directs that working mothers should be accorded paid leave or leave with adequate social security benefits. Furthermore, article 10(3) imposes an obligation on State Parties to take special measures for the protection and assistance for all children and young persons.

- Charter of Fundamental Social Rights in SADC. Article 10(1) of the SADC Charter obliges Member States to create an enabling environment so that every worker in the SADC region shall have the right to adequate social protection and shall, regardless of status and type of employment, enjoy adequate social security benefits.

\section{THE LABOUR MARKET AND SOCIAL PROTECTION CHALLENGES}

\subsection{The South African paradigm of two economies}

Commentators (academics and politicians alike) often observe that South Africa has the paradigm of two economies, namely the "first economy" and the 
"second economy". 45 The first economy is competitive, globally integrated and has export capabilities. The second economy is mostly made up of the unemployed and the "unemployable" and does not benefit from growth and opportunities that are available in the first economy. According to the Government's Programme of Action (GPA), ${ }^{46}$ millions of people can be found on the edges of the first economy, without a steady income and reliant on their own economic activity without an income-generating asset. Certain interventions have been identified for the development of the second economy. They include:

- ensuring mobility to the first economy;

- creating conditions for sustainable livelihood;

- reducing dependence on social grants; and

- eliminating conditions of extreme poverty. ${ }^{47}$

As will be shown below, however, the informal or second economy seems to be growing and mobility between the two economies is severely curtailed.

\subsection{Labour market indicators}

Informal economy surveys in some Southern African countries are either absent or outdated. This makes it difficult to form a complete statistical picture of this sector in the region. ${ }^{48}$ However, available data shows that the informal economy is growing. According to Olivier, the rise in non-traditional and, in particular, informal employment is usually associated with increasing job insecurity and precarious conditions of work. He describes the growth in the informal economy as a percentage of total GDP in Sub-Saharan Africa as having

\footnotetext{
${ }^{45}$ See, for example, the contributions in (2007) 37 Africanus: Journal of Developmental Studies 1-288.

46 Of June 2001, available at www.nedlac.org.za. See also Government of RSA Ten Year Review (2003).

47 GPA 2001.

48 This situation is largely attributed to the fact that informal sector surveys in most African countries are carried out on an ad hoc basic or are reliant on donor funding: United Nations Economic and Social Council (Economic Commissions for Africa) Report on the Status of the Compilation of Basic Economic Statistics in Africa (2008) 2.
} 
grown from 30 percent in 1990 to 39 percent in $2003 .{ }^{49}$ The estimate of informal employment as a proportion of non-agricultural employment per region is of concern: ${ }^{50}$

\section{Regional percentage of informal employment:}

$\begin{array}{ll}\text { North Africa } & 48 \\ \text { Sub-Saharan Africa } & 72 \\ \text { Latin America } & 51 \\ \text { Asia } & 65\end{array}$

The National Bureau of Statistics of Tanzania reports that one in every three households in Tanzania had some informal sector activity in 2000/01 as compared to one in every four households in 1990/91. ${ }^{51}$ On the other hand, a Central Statistics Office survey on living conditions in Zambia, carried out in 2004 , found that 81 percent of all employed persons in Zambia were engaged in the informal economy ${ }^{52}$ In this survey informal employment was defined as "employment where the employed persons were not entitled to paid leave, pensions, gratuity and social security and worked in an establishment employing five (5) persons or less". Secondly, informal economic activities could be found in both rural and urban areas ${ }^{53}$ and, in some countries, the

\footnotetext{
49 Olivier "Extending employment injury and disease protection to non-traditional and informal economy workers: The quest for a principled framework and innovative approaches" (2007) Obiter 418 at 419.

50 Valodia, Lebani and Skinner "Low-waged and informal employment in South Africa" at 17: table adapted from ILO Women and Men in the Informal Economy, A Statistical Picture (2002) 7.

51 National Bureau of Statistics (Tanzania) Integrated Labour Force Survey, 2000/01 Analytical Report (2003) 58 available at http://www.tanzania.go.tz/ilfs.htm.

52 Koyi "Dealing With the Informal Economy: A Challenge for Trade Unions in Southern Africa. Trade Union Involvement in the Informal Economy in Zambia" Friedrich Ebert Stiftung FES/LARRI Regional Workshop on Dealing with the Informal Economy: A Challenge for Trade Unions in Southern Africa (Windhoek, 11-12 October 2006).

53 See, e.g., Potts "The urban informal sector in sub-Saharan Africa: From bad to good (and back again?)" (2008) Development Southern Africa 151; National Bureau of Statistics (Tanzania) Integrated Labour Force Survey, 2000/01 - Analytical Report (2003) 58 available at http://www.tanzania.go.tz/ilfs.htm and World Bank "Zambia, 1998 - Living Conditions Monitoring Survey II, 1998" (2003) 5 Standardized Survey Bulletin 1.
} 
percentage of informal sector workers who did not complete their secondary education is high. According to the Economic Policy Institute Global Policy Network in South Africa, 95 percent of all informal economy workers have not completed high school and 85 percent of these workers are black. ${ }^{54}$

There is also a gender dimension to informal economy work. For instance, the aforementioned Central Statistics Office survey on living conditions in Zambia shows that informal economy employment was more common among females than males (89 as opposed to 74 percent). To further illustrate the vulnerable position of women in the labour market, only 11 percent of women in Zambia have jobs in the formal sector. 55

According to Mhone, ${ }^{56}$ the problems of poverty and the lack of adequate productive employment opportunities are directly linked to the problems of growth and development. He submits, correctly it is suggested, that in the African context it would be erroneous to assume that these problems can be resolved primarily through growth alone:

"Essentially, the countries of the sub-region have evolved what may be labelled as enclave economies in which growth has been predicated on a narrow economic base represented by the formal sector. This formal sector while accounting for the greater proportion of gross domestic product and economic growth only accounts for a very small proportion of employment. Thus the fundamental problem the countries are confronted with is that, for almost all of the countries except South Africa and Mauritius, the majority of the labour force still ekes out a living in the non-formal sectors of economy comprising small holder agriculture, rural non-farm activities and urban informal activities."

With reference to South Africa another economist, Terreblanche has commented as follows: ${ }^{57}$

"But what is perhaps of greater importance, is that it will be counter productive to intervene in the 'second economy' while the 'structure', the macro economic policy and the neo-liberal privileges granted to the corporate sector remain intact in the 'first economy'. It is highly necessary to move towards a truly

\footnotetext{
${ }^{54}$ Avirgan, Bivens and Gammage (eds) Good Jobs, Bad Jobs, No Jobs: Labor Markets in Egypt, El Salvador, India, Russia and South Africa (2005).

55 Ibid at 4.

56 Mhone Southern Africa: Socio-Economic Background (Research Paper 2002). The author has a copy of this paper on file.

57 Terreblanche "An evaluation of macroeconomic policy in the democratic Era" (2005) on file with author.
} 
developmental state system in South Africa. But this system cannot be created in the 'second economy'. It will have to be created in the South Africa economy as an undivided entity".

Many commentators have cautioned against the idea that, within individual countries, deregulation of the labour market may be seen as a main vehicle for attempting to promote employment. It must also be recognised that labour market regulation in a country such as Mozambique, with very low per capita income, does not have to be the same as in a country such as South Africa.

\subsection{Problems relating to the reach of social protection measures}

The right to social protection (or social security) does not always translate into access for those most vulnerable. This is discernable from the widespread exclusion and marginalisation of most informal economy workers from social protection schemes, particularly social insurance, in developing countries. ${ }^{58}$ This can be attributed to a variety of non-exhaustive factors:

- Coverage. Southern African countries, with few exceptions (e.g. South Africa and Mauritius), have limited social protection measures, particularly those of a social insurance nature. As one commentator puts it:

"Social insurance coverage (employer-employee contributions for health, retirement and work-related contingencies) as a mandatory contributory system of one kind or another in the region has remained rudimentary." 59

Furthermore, social protection schemes in these countries are more oriented towards the protection of those persons employed in the formal sector. ${ }^{60}$ There are often legal barriers to social protection for informal economy workers. This is evident from the legal framework of most social insurance and labour laws which restrict access to or participation in these schemes to those workers who fit the definition of the term "employee" or

\footnotetext{
${ }^{58}$ See, for example, Olivier and Mpedi "The extension of social protection to non-formal sector workers - experiences from SADC and the Caribbean" (2005) 19 ZIAS 144 and Mpedi "Unemployment protection in the Southern African Development Community: Trends and Challenges" (2008) 22 ZIAS 271 at 276-281.

59 Taylor "Social protection challenges in Southern Africa" (2001) Cooperation South 49 at 51.

${ }^{60}$ See Kaseke "Social exclusion and social security: The case of Zimbabwe" (2003) 18 Journal of Social Development in Africa 33 and Mouton Social Security in Africa: Trends, Problems and Prospects (1975) 3.
} 
similar terms such as a "contributor". Self-employed persons are generally excluded, even from voluntary participation.

- Benefits. Social insurance benefits are awarded subject to a variety of qualifying conditions. These conditions include contributions ${ }^{61}$ and a qualifying period. ${ }^{62}$ The low level and irregularity of the income of most informal economy workers significantly affects their contributory capacity. Secondly, it is true that social insurance schemes provide both short-term and long-term benefits. However, these benefits, particularly the long-term benefits, may at times be inappropriate for informal economy workers. The point is that many workers in the informal economy are concerned about the so-called "here and now risks" (e.g. providing for an empty stomach) and not about risks that may occur in future.

- Financing. The low level and irregularity of the income of the majority of informal economy workers impede their participation in social insurance schemes. ${ }^{63}$ Another point to be noted is that formal sector employees share the contributions with their employers. Thus, informal economy workers may be reluctant to pay the full contributions by themselves. ${ }^{64}$ This is hardly surprising, as many of these workers live from hand to mouth. The case is, of course, much different for professional self-employed persons.

- Administration. Employers in the formal economy play a key role in easing the challenge of administering social insurance schemes by acting as intermediaries between social insurance schemes and their employees. They register with social insurance schemes, remit the names of their employees for registration and transfer the corresponding sums of money for the employer's and employees' contributions. Despite the employer's involvement, the collection of contributions remains a difficult challenge for most social insurance schemes. The administrative challenges of collecting contributions are even more daunting for informal economy workers, particularly where there are no intermediaries (i.e. employers). However, the incorporation of domestic workers in the South African unemployment insurance systems appears to be progressing satisfactorily.

\footnotetext{
${ }^{61}$ Except in the case of workers' compensation for occupational injuries and diseases, where employers generally finance the compensation schemes.

${ }^{62}$ Qualifying periods are also not applicable in the case of workers' compensation.

63 ILO Decent Work and the Informal Economy (2002) at 58.

${ }^{64}$ Ibid.
} 
This is the case, despite the scepticism expressed in some quarters prior to their inclusion.

It is unfortunate that no clear interventions have been identified to address the extension of social insurance measures to those employed in the informal economy. Despite the sentiments of the GPA of 2001, government seems not to see this as a priority area. During the Social Cluster Briefing regarding "Second economy interventions and poverty alleviation" by the then Minister of Social Development, Dr Zola Skweyiya, social insurance was not even on the agenda. ${ }^{65}$ In response to a call by President Thabo Mbeki in his 2006 State of the Nation Address to "move faster to address the challenges of poverty, underdevelopment and marginalisation confronting those caught within the Second Economy" Dr Skweyiya elaborated on the programmes that would be focused on in this regard. ${ }^{66}$ The programmes included the following:

- Comprehensive social security: in particular, improving the efficiency and effectiveness of social grants spending and reducing the risk of the abuse of social grants, as well as the establishment of the South African Social Security Agency (SASSA). (At present this agency is only occupied with the payment of social assistance grants.)

- Housing and human settlement: including broadening housing finance to the lower and middle income groupings.

- Integrated food security and land reform: including enabling rural farmers to have access to finance for their agricultural enterprises, as well as reconsideration of the current approach to land acquisition which depends largely on the willing-buyer-willing-seller principle.

- Expanded public works programmes, viewed as an important bridge between the two economies and a significant part of poverty alleviation. Creating jobs and learnerships are envisaged under this initiative.

- An integrated sustainable rural development programme and urban renewal programme. As part of the social wage package local government will be assisted to deliver services and partnerships with the private sector and the donor community for various projects. Included is a national

\footnotetext{
65 See Social Cluster Briefing, Parliament, Cape Town, 7 February 2006; available at http://www.polity.org.za/article/skweyiya-parliamentary-media-briefing-february-200607022006-2006-02-07.

66 Ibid.
} 
research and strategy development project to produce detailed economic profiles of all the nodes as well as proposals for economic development. ${ }^{67}$

Although these efforts are necessary and to be welcomed, it is unfortunate that extending social insurance coverage, strengthening of informal social security measures, increased economic growth and the strengthening of linkages between the first and second economies are not specifically addressed. Although access to social grants is important, this should not be the main focus of a poverty alleviation strategy. Concrete measures should be put in place to extend social protection coverage to informal economy workers or, alternatively, strategies should be developed to make it possible for them to finance their own insurance schemes with the State playing some role as guarantor. Clearly this is a multi-faceted problem that requires a versatile response. There are, however, many hurdles, as is highlighted in the 2007 annual report of the Accelerated and Shared Growth Initiative for South Africa: ${ }^{8}$

"The review of existing Second-Economy programmes within national government is now complete. While progress is being made in certain areas, the review confirmed concerns about the limited scale of impacts of current programmes....

"At a more programmatic level, the main obstacles to scaling up include the following:

- Underfunding or funding that is dependent on redirecting existing departmental budgets: This is the case with, among other things... integrated rural development and local economic development programmes. Different funding arrangements are needed, as well as a greater recognition that achieving greater impacts will require innovation and a level of risk.

- Co-ordination and implementation problems in government: Most SecondEconomy programmes require interdepartmental co-operation. The lead department should not have line-function authority over other departments, and accountability is often hard to assert. This is a key challenge.

- Lack of voice and advocacy: In many key areas, scaling up would be helped along greatly by stakeholder organisations able to lobby and advocate on their own behalf - whether smallholders in the forestry sector negotiating terms of access as part of a sector strategy, or street traders clarifying their needs in interaction with municipalities. By definition, marginalised groups are seldom well organised.

${ }^{67}$ ibid.

68 Accelerated and Shared Growth Initiative for South Africa (AsgiSA) Annual Report (2007) at 34 et seq.; available at http://www.thepresidency.gov.za/docs/reports/asgisa/initiatives.pdf. 
- The interface between government programmes and markets: Creating employment and access to economic opportunities depends to varying degrees on the interface between government and wider markets. Government needs to get better at identifying and using tools that are able to catalyse change in the outcomes achieved in markets and from within the private sector.

- Low targets and a project-level focus: Many Second-Economy programmes remain focused at a project level. While this may be of vital benefit to participants, it leaves wider structural blockages and market failures unchanged."

\section{RECOMMENDATIONS TO ADDRESS THE PLIGHT OF THOSE WORKING IN THE INFORMAL ECONOMY}

Internationally, it has been noted before that attempts to link formal and informal social security generally result in two main approaches. The first is to extend or to modify the existing formal social security system to also cover those who are at present excluded. Therefore, this approach is aimed at the extension of the formal system. The second approach is where the state recognises existing informal systems of social protection through, for example, providing financial support to individuals and organisations operating within this framework or even by attempting to incorporate such well-known and supported practices into statutory systems and schemes.

Van Ginneken argues that, logically, social security for the informal economy workers and their dependants should first of all cover those who may be able to contribute to their own insurance from their employment income. ${ }^{69}$ He therefore identifies three major ways in which social security can be promoted for informal economy workers and their dependants:

- through specially designed social insurance schemes; ${ }^{70}$

\footnotetext{
${ }^{69}$ Van Ginneken (n 6). Van Ginneken further argues that workers who have "informal labour relations" with their employers, i.e. in the absence of written contracts, should also be covered. Here, the categories of home workers, causal workers and so forth are relevant. In the last instance, some groups (such as widows, orphans and old people) should then be protected by social assistance.

70 Pre-requisites, according to Van Ginneken, are the existence of an association based on trust and an administration that is capable of collecting contributions and providing benefits. According to Chen et al (n 8) 42 the following criteria are important when designing schemes supportive of informal workers (developed by Lund and Srinivas): they should not download most of the responsibility for risk coverage on to poor people themselves; they should keep open the possibility for different contributions from different stakeholders; they should be able to go to scale; they should emphasise women's empowerment; they should take into
} 
- through social assistance; ${ }^{71}$ and

- through the extension and reform of formal sector social insurance schemes.

It must, however, be remembered that workers with low earnings and irregular employment face many difficulties in saving enough to protect themselves against risks, either individually or through informal groups. Chen et al therefore conclude that

"[i]n sum, informal social security mechanisms and mutual insurance schemes should not be seen as a substitute for more formal mechanisms, especially given the increasing risks and volatility associated with globalisation and economic transitions more generally." 72

When attempting to give meaning to the Decent Work Agenda one may have regard to four strategic objectives: ${ }^{73}$

- promoting and realising standards and fundamental principles and rights at work;

- creating opportunities for women and men to secure decent employment and income;

- enhancing the coverage and effectiveness of social protection for all; and

- strengthening tripartism and social dialogue.

It is not surprising that all these are long-term strategic goals. We will now consider some measures that may be suitable for earlier implementation.

Rendering social insurance relevant for informal economy workers is easier said than done. However, policymakers in developing countries need to be conscious of the fact that this task is a necessity and not an option. For instance, in South Africa the State has a constitutional obligation, subject to the availability of resources, to progressively extend social security, inclusive of

account the unpaid work and domestic responsibilities that women have and how this is often done simultaneously with informal paid work; and they should address the local government context.

${ }^{71}$ This could include social assistance for specific occupational groups; e.g. the Indian labour welfare scheme targeting the beedi/bidi (cigarette) workers, cine workers and some mineworkers, which benefits are financed by earmarked tax. See the Bidi Workers Welfare Fund, discussed in Chen et al (ibid) 39.

72 Ibid at 40.

${ }^{73}$ See Trebilcock (n 16) at 6. 
social insurance, to those not covered. ${ }^{74}$ There are a variety of points that need to be considered.

Firstly, the "employee" definitional hurdle, which excludes most informal economy workers from social insurance schemes, needs to be addressed. This could be done by broadening this concept in social security laws, as was done in other South African labour statutes. ${ }^{75} \mathrm{~A}$ wide interpretation of the notion of "employee" as found in current definitions in labour legislation is possible; it has simply not been done in South Africa. ${ }^{76}$ The issue of "economic dependency" features strongly in such a wider interpretation. Sections 198 of the LRA and 83 of the BCEA make provision for ways to include workers under triangular employment relations and so-called "deemed" employees. There are signs that the Labour Court is more willing to give a wide interpretation to the definition of employee (at least the ones contained in the labour statutes). Recently, for example, a foreigner working without a valid work permit was found to qualify as an employee. ${ }^{77}$

The South African sectoral determination approach could also be useful in this regard. Section 51(1) of the BCEA empowers the Minister of Labour to issue a sectoral determination establishing basic conditions of employment for workers in a sector and area. In 2005, the Sectoral Determination 11: Taxi Sector 2005 brought the South African taxi sector ${ }^{78}$ within the ambit of the unemployment insurance scheme. Sectoral determinations are undoubtedly a practical means by which social insurance can be extended to excluded and marginalised persons who eke out a living in the informal economy. This is particularly so in cases where employers and their employees are easily identifiable. Nonetheless, sectoral determinations have their shortcomings. For example, they extend social insurance coverage in a piece-meal fashion.

${ }^{74}$ S 27(2) of the Constitution.

75 As previously noted, this is necessary as the labour law definition of "employee" usually serves as a gatekeeper for access to social insurance. See also par 2.2 above.

76 Benjamin "An accident of history: Who is (and who should be) an employee under South African labour law" (2004) 25 ILJ 787 reminded us more than a decade ago that "[t]hese definitions ... [of who is an employee in South African labour statutes] are open to an expansive interpretation, but the courts have preferred to interpret them conservatively."

77 Discovery Health Limited v CCMA \& others (2008) 29 ILJ 1480 (LC). See also Bosch "Can Unauthorized Workers be Regarded as Employees for the Purposes of the Labour Relations Act?" (2006) 27 ILJ 1342.

78 See clause 34(1) of the Sectoral Determination 11: Taxi Sector 2005 for the definition of "taxi sector". 
This means "it is left to a political office-bearer [the Minister of Labour] to adopt measures if and when he/she deems it appropriate to do so, and not to parliament to regulate coverage extension in the law itself."79

Secondly, existing social insurance schemes could, where possible, be adapted so as to facilitate partial or voluntary participation ${ }^{80}$ by the selfemployed as well as other categories of persons working in the informal economy. ${ }^{81}$ Even so, one must recognise that the paltry income of some informal economy workers may make it impossible for them to contribute towards the voluntary social insurance schemes. In addition, voluntary insurance schemes should take into account the fact that employers usually share the social security contributions burden with their employees. Regarding the first issue, a fixed scale of contributions that corresponds to earnings could be developed. There are two ways of dealing with the latter issue. In the first instance, informal economy workers could be required to contribute only the employee's portion towards a particular social insurance scheme. Ultimately, the value of benefits paid must be commensurate with the contribution rate. The second option would require informal economy workers to contribute both the employee and employer portions of the contribution. This option may not attract informal economy workers with meagre incomes.

In addition, ways and means to make social insurance benefits suitable for informal economy workers' needs should be explored. This is not a call for the substitution of social insurance benefits providing cover for the traditional social risks, particularly long terms benefits such as old age, invalidity and unemployment. Other social insurance benefits such as those aimed at covering the livelihood of informal economy workers need to be found, even if it means introducing social insurance schemes specifically aimed at these workers and providing for such kinds of benefits. In this regard, the integration or interlinking and strengthening of informal social security measures (stokvels or rotating savings and credit clubs) common among

\footnotetext{
79 Olivier and Mpedi (n 2) at 157.

80 Voluntary participation in social insurance schemes by informal economy workers (e.g. the self-employed) can be found in developing countries such as Belize and Seychelles.

${ }^{81}$ See Beattie "Social protection for all: But how" (2000) 139 International Labour Review 129 at 139-142, Bailey "Extending the range of social protection" in ILO Reflections on Reform Strategies for Social Protection in English-Speaking African Countries (2000) 33 at 68-70 and Van Langendock "The social protection of the unemployed" (1997) 50 International Social Security Review 29 at 34.
} 
informal economy workers in developing countries are of paramount importance. ${ }^{82}$

Furthermore, the administrative capacity of the current social insurance schemes - particularly in areas such as compliance and enforcement, collection of contributions, maintenance of contributors' records and financial management - should be improved. In South Africa the unemployment insurance system has successfully extended its scope to "informal" workers, namely domestic workers. In principle there is no reason why, for example, workers' compensation could not follow suit. In the case of self-employed persons voluntary participation must be an option. Additionally, educational and awareness campaigns to enhance knowledge and understanding of the operation of social insurance schemes should be launched. This is crucial in addressing concerns pertaining to administrative challenges associated with the extension of social insurance to informal economy workers, such as fraud.

Emphasis needs to be placed on women and woman-headed enterprises, which constitute a big percentage of small, medium and micro-enterprises. Targeted programmes could convince these employers and employees to register and become part of the formal economy or to link up with it.

More needs to be done to implement skills development programmes. The view that people working in the informal economy are "unemployable in formal economy" is partly true and partly false. However, the migration between the two economies is made easier where workers can show that they have attended skills-building programmes or that they have worked casually in the formal economy. The expanded public works programmes are a good start but much more needs to be done in this area.

Trade union involvement in the informal economy must be improved and extended: The exclusion and marginalisation of informal economy workers from social security, particularly social insurance, is aggravated by the fact that there is limited trade union involvement in the informal economy. The small size of the formal economies in the region creates a real danger for trade unions; their membership base and coverage are increasingly being eroded. ${ }^{83}$

\footnotetext{
82 See Olivier et al "Formulating an Integrated Social Security Response - Perspectives on Developing Links between Informal and Formal Social Security in SADC Region" Paper presented the EGDI-WIDER Conference on Unlocking Human Potential: Linking the Informal and Formal Sectors, Helsinki, Finland, 17-18 September 2004.

${ }^{83}$ See Du Toit "What is the Future of Collective Bargaining (and Labour Law) in South Africa?" (2007) 28 ILJ 1405.
} 
To remedy this situation, it is suggested that trade unions should be encouraged to help organise workers in the informal economy. This could include assisting informal economy workers to organise themselves by means of capacity-building exercises, placement with temporary employment services, participation in adult literacy programmes and so forth. Greater trade union involvement, it is submitted, has a strong potential of providing informal economy workers with a voice to garner support for their inclusion under various social protection measures.

\section{CONCLUDING REMARKS}

This article argues for increased coverage of formal social insurance schemes of employees, including atypical employees, working in the informal economy. As pointed out earlier, this is one way to improve the social protection of these workers. However, other mechanisms can also be utilised to achieve the same goal. These include the extension and strengthening of informal social security measures and the extension of the current social grants. Extension of the reach of social insurance schemes is not aimed at undermining the importance of these mechanisms in enhancing social protection. The point is that, where possible, workers should be able to contribute towards their own protection through officially guaranteed social protection schemes. In this way, through social insurance participation, workers take (collective) responsibility for their future protection against social risks - with solidarity playing an important role and the State (through social assistance) and informal social security systems playing a residual role. The motivation for this approach includes the fact that benefits payable under social insurance schemes are generally higher (often earnings-related) and the sustainability of these schemes are not as risky as informal measures. The sustainability, and desirability, of an extended social grants system is a controversial topic which falls outside the reach of this contribution.

The economy, just like a coin, has two sides - the informal economy and the formal economy; and while this is true of many economies of the world, one needs to distinguish between the developed world and developing world economies. Developed countries, unlike developing countries, have well-built formal economies. Well-built formal economies favour formal employment. Formal employment invariably leads to (better) social security coverage. The situation in developing countries is quite the opposite. To begin with, the formal sector is very small. When these slender formal economies shed jobs in droves, a substantial part of the labour force seeks succour in the informal 
economy. In developing countries, due to weak and/or non-existent safety nets, poor people find it difficult to survive without income-generating activities, which leads to a rise in informal employment. In this article it has been reaffirmed that persons employed in the informal economy are as a rule excluded and marginalised from formal social security schemes - particularly those of an insurance nature. Thus, most informal economy workers are left at the mercy of social risks or rely on informal coping strategies, which are at times unable to withstand challenges such as long-term unemployment.

With the forgoing pronouncements in mind, it is of the utmost importance that informal economy workers in developing countries be brought within the ambit of social security schemes - particularly those of an insurance nature. Without claiming to have spoken the final word on this subject, the following points raised in this paper are once more emphasised in conclusion. Firstly, the labour law concept of "employee", which serves as gatekeeper to social insurance, has to be interpreted more widely. Secondly, social insurance schemes have to be adapted so as to make them amenable to partial or voluntary participation by informal economy workers. Thirdly, options for making social insurance benefits suitable for those working in the informal economy should be further investigated. Fourthly, the administrative capacity of the present social insurance schemes in areas such as compliance and enforcement, collection of contributions and financial management should be improved. Furthermore, the informal coping strategies of people should be reinforced and, where possible, formalised. Most importantly, trade union involvement and solidarity with those eking out a living in the informal economy should be encouraged.

\section{BIBLIOGRAPHY}

\section{Books, journals and other publications}

Accelerated and Shared Growth Initiative for South Africa (AsgiSA) Annual Report (2007).

Avirgan, T. Bivens, J. \& Gammage, S. (eds) Good Jobs, Bad Jobs, No Jobs: Labor Markets in Egypt, El Salvador, India, Russia and South Africa (Washington, D.C. Economic Policy Institute 2005). 
Bailey, C. "Extending the range of social protection" in ILO Reflections on Reform Strategies for Social Protection in English-Speaking African Countries (ILO, 2000) 33.

Barrientos, A. "Extending social protection for women informal workers in Latin America" (unpublished paper, 2005).

Beattie, R. "Social protection for all: But how" (2000) 139 International Labour Review 129.

Benjamin, P. "An accident of history: Who is (and who should be) an Employee under South African labour law" (2004) 25 ILJ 787.

Bosch, C. "Can Unauthorized Workers be regarded as Employees for the Purposes of the Labour Relations Act?" (2006) 27 ILJ 1342.

Braude, W. "South Africa: Bringing informal workers into the regulated sphere, overcoming Apartheid's legacy" in Avirgan et al (eds) Good Jobs, Bad Jobs, No Jobs: Labor Markets and Informal Work in Egypt, El Salvador, India, Russia and South Africa (Economic Policy Institute, 2005).

Chen, M. "Rethinking the Informal Economy: Linkages with the Formal Economy and the Formal Regulatory Environment" (DESA Working Paper No. 46, 2007).

Chen, M. Jhabvala, R and Lund, F. "Supporting Workers in the Informal Economy: A Policy Framework" (ILO, 2001).

Dekker, A. "Can Informal Social Security assist Government to Guarantee Everyone a Right of Access to Social Security?" (LLD thesis, UNISA, 2008).

$\mathrm{Du}$ Toit, D. "What is the Future of Collective Bargaining (and Labour Law) in South Africa?" (2007) 28 ILJ 1405.

Haddad, L. (ed) Achieving Food Security in Southern Africa: New Challenges, New Opportunities (International Food Policy Research Institute, 1997).

Humblet, M \& Silva, R. (2002) Standards for the XXIst Century: Social Security (ILO, 2002).

Hussmanns, R. "Measuring the informal economy: from employment in the informal sector to informal employment" (ILO Bureau of Statistics, Working Paper No. 53, Geneva, 2005).

International Labour Office Decent Work and the Informal Economy (Resolution adopted by International Labour Conference, $90^{\text {th }}$ Session, Geneva, 2002). 
International Labour Office Report of the Director General: Decent Work (87 Session, Geneva, 1999).

Kaseke E "Social exclusion and social security: The case of Zimbabwe" (2003) 18 Journal of Social Development in Africa 33.

Koyi, G. "Dealing With the Informal Economy: A Challenge for Trade Unions in Southern Africa: Trade Union Involvement in the Informal Economy in Zambia" (Friedrich Ebert Stiftung, Lusaka, 2007).

Mhone, GCZ. "Atypical Forms of Work and Employment and Their Policy Implications" (1998) 19 ILJ 197.

Mhone, GCZ. Southern Africa: Socio-Economic Background (Research Paper, 2002).

Midgley, J. \& Sherraden, M. (eds) Alternatives to Social Security: An International Inquiry (Auburn House, 1997).

Mills, SW. "The situation of the elusive independent contractor and other forms of atypical employment in South Africa: Balancing equity and flexibility" (2004) 25 ILJ 1203.

Mouton P Social Security in Africa: Trends, Problems and Prospects (ILO, 1975).

Mpedi, LG. "Unemployment protection in the Southern African Development Community: Trends and Challenges" (2008) 22 Zeitschrift für ausländisches und internationales Arbeits- und Sozialrecht 271.

National Bureau of Statistics (Tanzania) Integrated Labour Force Survey, 2000/01 - Analytical Report (2003). Available at http://www.tanzania.go.tz/ilfs.htm.

Olivier, MP. "Extending Labour Law and Social Security Protection: The Predicament of the Atypically Employed" (1998) 19 ILJ 669.

Olivier, MP. "Extending employment injury and disease protection to nontraditional and informal economy workers: The quest for a principled framework and innovative approaches" (2007) Obiter 418.

Olivier MP. et al "Formulating an Integrated Social Security Response Perspectives on Developing Links between Informal and Formal Social Security in SADC Region" (Paper presented at the EGDI-WIDER Conference on "Unlocking Human Potential: Linking the Informal and Formal Sectors" Helsinki, Finland, 17-18 September 2004). 
Olivier, MP and Mpedi, LG. "The extension of social protection to non-formal sector workers - experiences from SADC and the Caribbean" (2005) 19 Zeitschrift für ausländisches und internationales Arbeits- und Sozialrecht 144.

Potts, D. "The urban informal sector in sub-Saharan Africa: from bad to good (and back again)" (2008) 25 Development Southern Africa 151.

Shrestha, A. "Social protection in the informal economy" (Paper presented in National Consultation Workshop "Identifying Challenges of Informal Economy for Trade Unions", organised by DECONT at Lalitpur, India, on 15-16 May 2004).

Smit, N. "Decent work and the promotion of access to social protection for workers in the informal economy - an international and regional perspective" (2007) 4 TSAR 700.

Statistics South Africa Labour Force Survey: September 2007.

Taylor, V. "Social protection challenges in southern Africa” (2001) Cooperation South (2) 49.

Terreblanche, S. "An evaluation of macroeconomic policy in the democratic Era" (Paper presented at COSATU Conference on 10 Years of Democracy, Johannesburg, 6 March 2005.

Theron, J. "Atypical forms of work and employment and their policy implications" (1998) 19 ILJ 197.

Theron, J. “Employment is not what it used to be" (2003) 24 ILJ 1247.

Thompson, C. “The Changing Nature of Employment” (2003) 24 ILJ 1793.

Trebilcock, A. "Decent Work and the Informal Economy" (Discussion paper No 2005/04, UNU-WIDER, Helsinki, 2005).

United Nations Economic and Social Council (Economic Commissions for Africa) Report on the Status of the Compilation of Basic Economic Statistics in Africa (2008).

United Nations Enhancing Social Protection and Reducing Vulnerability in a Globalising World: Report of the Secretary-General 39th Session of the Commission for Social Development (2000).

Valodia, I. "Formal/informal linkages in South Africa: some considerations" (HSRC, 2006). 
Valodia, I. Lebani, L \& Skinner, C. A review of labour markets in South Africa: Low-waged and informal employment in South Africa (Commissioned by SIDA, 2005).

Van Ginneken, W. "Social security for the informal sector: Issues, options and tasks ahead" (ILO Working Paper, 1996).

Van Ginneken, W. "Extending social security: Policies for developing countries" (ESS Paper No 13, 2003).

Van Langendock, J. "The social protection of the unemployed" (1997) 50 International Social Security Review 29.

\section{Case Law}

Discovery Health Ltd v CCMA \& others (2008) 29 ILJ 1480 (LC).

Independent Municipal and Allied Trade Union and Another $v$ City of Cape Town (2005) 10 BLLR 1084 (LC).

\section{Legislation}

Basic Conditions of Employment Act 75 of 1997.

Compensation for Occupational Injuries and Diseases Act 130 of 1993.

Employment Equity Act 55 of 1998.

Labour Relations Act 66 of 1995.

Occupational Health and Safety Act 85 of 1993. 